\title{
Chemical and Mineral Compositions of Ostrich (Struthio camelus) egg in Southern Guinea Savanna of Nigeria
}

\section{Rasheed S. Amao}

\author{
Department of Agricultural Education (Animal Sci. Division; Animal Breeding \& Genetics \\ unit), School of Vocational and Technical Education, Emmanuel Alayande College of Educa- \\ tion, P.M.B.1O1O. Oyo. Oyo State. Nigeria.
}

*Correspondence should be addressed to Amao: sholaamao@gmail.com, sholaamao@eacoed.edu.ng

Received 11 March 2019; Revised 31 May 2019; Accepted o5 June 2019

(C) 2019 Amao. Licensee Pan African Journal of Life Sciences. This is an Open Access article distributed under the terms of the Creative commons Attribution License (https://creativecommons.org/licenses/BY/4.o), which permits unrestricted use, distribution, and reproduction in any medium, provided the original work is properly cited.

Introduction: Egg quality and its components are important indices to consumers, and the economic success of producers depend on the total number of eggs sold. Egg quality is based on the characteristics of the eggs that affect its acceptability, and the egg components are of nutritional importance. Therefore, the study was carried out to determine the chemical and mineral compositions of ostrich eggs found in southern guinea savannah environ of Nigeria.

Methods: Eighty freshly laid eggs were obtained from Ostrich birds in Old Oyo National Park and were used for the experiments. Data were obtained for chemical composition on moisture, carbohydrate, protein, lipid, cholesterol and ash components separately for both albumen and yolk of the eggs while mineral composition observed were Potassium, Calcium, Magnesium, Phosphorus, Iron, copper, Zinc and Manganese.

Results: The findings on chemical composition revealed that the protein (17.35), moisture (85.59) and ash contents (1.90) were significantly $(\mathrm{p}<0.05)$ higher in albumen than in yolk. The carbohydrate (0.98), lipid (30.47) and cholesterol (13.40) contents mean percentages were higher in yolk than in albumen. The mineral compositions of albumen and yolk of ostrich eggs indicated that the yolk as a content had the higher values of 135.35, $380.40,20.35,10.38,2.25,1.85$ and 2.50 ppms in calcium, phosphorus, magnesium, iron, copper, zinc and manganese respectively than these variables in albumen while albumen contents was only higher in potassium (160.25 ppm) than in the yolk.

Conclusion: It can be concluded that the information provided in this study could be a template of criteria for comparison and improvement for Ostrich eggs in the environment.

Keywords: Ostrich eggs, Chemical, Mineral, Southern guinea savannah 


\section{O INTRODUCTION}

Ostriches are famous for curiosity and they as well attract special attention because of their bright colour [1]. Farming of ostrich in Nigeria is unpopular [2] whereas ostrich industry is growing rapidly in many countries of the world such as United State of America, Australia, Canada, Zimbabwe, Botswana, Egypt, South Africa, Kuwait and several European countries [3, 4, 5, 6, 7]. Recent interest in ostrich management has led to an increasing demand for information and how to manage it commercially $[8,9]$. Ostriches will start laying eggs around the first of April and continue laying as late as the end of $\mathrm{Au}-$ gust. Eggs are laid about every other day, with an average of about 40 eggs laid per year of incubation period of about 42 days [10]. Factors determining growth in ostriches are similar to those in other avian species. These factors include diet, rearing environment, genetic potential, management [11] and health status [12].

The eggshell is the natural packing material for egg contents and it is important to obtain high shell strength to resist all impacts an egg is subjected to during the production chain [13]. Mertens et al [14] indicated that cracked eggs cause economic loss in three ways; they cannot be sold as first-quality eggs, the occurrence of cracks raises the risk of bacterial contamination, leaking eggs cause problems with internal and external quality as well as food safety. The majority of eggs are sold in their shell and a consumer's first impression of an egg is influenced by their perception of the shell quality.

Eggs are considered as one of the most important foodstuffs and probably one of the first multifunctional food ingredients. They are well known for their whipping, gelling and emulsification properties [15]. Eggs play an important role in supplying cheap proteins to the masses and add special features that helps during food preparation. The three most recognized property of eggs in food preparation are: liquid egg will coagulate or solidify when heated (to produce cakes, etc.); aeration (whipping) creates lighter and airier products (e.g. merengue); and emulsification of egg yolk phospholipids and lipoproteins will produce salad dressings and sauces [16].

Eggs contain 11\% protein, $11.2 \%$ fat, trace of carbohydrate and without fibres [17]. Most of the proteins are concentrated in the white part of the egg known as albumen or egg white, the egg albumen mostly contains water and proteins. The yolk is surrounded by the albumen and containing about $80 \%$ calories. Also, it contains vitamin $\mathrm{A}, \mathrm{D}, \mathrm{E}$ and $\mathrm{K}$ and minerals such as iron, calcium and phosphorus [17]. Component fat of an egg is found al- most entirely in the yolk; there are less than $0.05 \%$ of fat in the albumen.

Several factors influence the storage of eggs and these include temperature, length of storage [18], the movement of $\mathrm{CO}_{2}$ and moisture through the egg shell all of which can change the chemical composition of the eggs [17]. The yolk of a freshly laid egg is round and firm. As the yolk ages, it absorbs water from the albumen through vitelline membrane and increases in size and moisture percentage [19]. The production of high quality eggs is the responsibility of the poultry and egg producers and as such, quality must be preserved by them for consumers' acceptability. Consumers of eggs are keen to know the components of eggs that they consume which may have impact on their health. Poultry species have varying egg quality that dictates the consumers' acceptability and there are limited information on the characteristic quality of Ostrich eggs. Hence, this study was designed to evaluate the chemical and mineral properties of Ostrich (Struthio camelus) eggs obtained in the southern guinea environment of Nigeria.

\section{2.o MATERIALS AND METHODS}

\subsection{Experimental Site}

The study was carried out at the Poultry Unit of Teaching and Research Farm, Emmanuel Alayande College of Education, Oyo, Oyo State, Nigeria. This lies on the longitude 30 5' East of the Greenwich meridian and latitudes 705 ' North eastwards of Ibadan, the capital of Oyo State. The altitude is between 300 and 600 meter above sea level. The mean annual temperature and rainfall are $27^{\circ} \mathrm{C}$ and $1,165 \mathrm{~mm}$ respectively. The vegetation of the area is southern guinea savannah zone of Nigeria [20].

\subsection{Source of Eggs}

Freshly laid eggs of Ostrich were obtained from old Oyo National park, Oyo, Oyo State, Nigeria. A total of eighty freshly laid eggs were used for the evaluation of chemical and mineral traits of Ostrich (Struthio camelus) eggs.

\subsection{Chemical Analyses}

The Yolk was separated from the albumen and both were replicated in three glass beakers. The moisture, ash, protein, lipid and carbohydrates contents of albumen and yolk were analyzed in three replicates according to Association of Official Analytical Chemists [21]. Moisture contents were determined by drying samples of egg albumen and yolk in conventional oven at $98^{\circ} \mathrm{C}$ for $24 \mathrm{hr}$. Ash content was determined by ashing samples using 
muffle furnace oven at $600^{\circ} \mathrm{C}$ for $6 \mathrm{hr}$. Lipid analysis was conducted on all samples using mixture of ratio 1: 1 of chloroform to methanol and stirred for 20 minutes using magnetic stirrer for several times. Protein was determined by the method of semi-microkjeldal determination of Nitrogen \% and the values obtained were multiplied with 6.25 to calculate protein percentage. Carbohydrate was determined by subtracting moisture, ash, lipid and protein percentages from 100 [22]. Cholesterol was determined by ethanol-ferric chloride colorimetric methods using spectrophotometer (LKB Ultra spectronic) [23].

\subsection{Minerals Analysis}

The concentrations of total Phosphorus (P), Calcium (Ca), Magnesium (Mg), Potassium (K), Copper ( $\mathrm{Cu})$, Zinc $(\mathrm{Zn})$, Manganese (Mn) and Iron (Fe) of the eggs samples were determined using of Atomic Absorption Spectrometry method in accordance with Omana and $\mathrm{Wu}$ [24].Measurement of the absorbance was made at UVmini-1240 spectrophotometer at wavelength of $\mathrm{P}-\lambda=$ $430 \mathrm{~nm} ; \mathrm{Ca}-\lambda=422.7 \mathrm{~nm} ; \mathrm{Mg}-\lambda=285.2 \mathrm{~nm}$; $\mathrm{K}-\lambda=$ $589 \mathrm{~nm}, \mathrm{Fe}-\lambda=213.9 \mathrm{~nm}$ in comparison with the reference solution [25]. The concentrations of minerals were expressed as $\mathrm{mg} / 100 \mathrm{~g}$ fresh produce by calculating according to the weight of the sample and dilution made.

\subsection{Statistical Analysis}

All data collected were subjected to Analysis of Variance in a General Linear Model (GLM) using Statistical Analysis System Institute [26] while significant differences were computed using Duncan Multiple Range test to separate the significance of means $(\mathrm{P}<0.05)$.

\subsection{RESULTS AND DISCUSSION}

The result of the mean percentages and standard errors of chemical composition of albumen and yolk of ostrich eggs is as shown in Table 1. The findings revealed that the moisture and ash contents were higher in albumen having values of 85.59 and 1.90 respectively than in yolk. No lipid and carbohydrate was found in the albumen of the eggs analysed. The carbohydrate (0.98), lipid (30.47) and cholesterol (13.40) contents were higher in yolk than albumen for the values recorded for these variables while protein content was higher in albumen (17.35) than in the yolk. This implies that Albumen of Ostrich eggs is of moisture and ash content while carbohydrate, protein, lipid and cholesterol were found to be the major component of yolk of the eggs. The chemical composition of ostrich eggs in the present study revealed that albumen and yolk compositions in moisture, protein and
Table 1: Mean Percentage of chemical composition of albumen and yolk of ostrich eggs

\begin{tabular}{lll}
\hline Variable & Egg Albumen & Egg Yolk \\
\hline Moisture & $25.50 \pm 3.55$ & $47.35 \pm 12.67$ \\
Carbohydrate & $0.76 \pm 0.01$ & $0.48 \pm 0.02$ \\
Protein & $17.35 \pm 0.35$ & $10.24 \pm 0.58$ \\
Lipid & - & $30.47 \pm 0.88$ \\
Cholesterol & - & $13.40 \pm 0.54$ \\
Ash & $1.90 \pm 0.01$ & $1.53 \pm 0.04$ \\
\hline
\end{tabular}

ash were in line with the findings of Szczerbińska et al [27]. This might due to the fact the animal required a strong skeleton to build strongly mineralized bone tissue and this constitute the large quality of mineral elements in the yolk of ostrich eggs [27]. This result on chemical composition of ostrich eggs was also in harmony with the reports of Selvan et al [28] in Indian. The values reported by these researchers were in the same range with the present study for albumen and yolk contents in term of chemical compositions. Also, the chemical composition of albumen and yolk of the eggs in the presently study is comparable to the reports obtained in domestic subspecies of ostrich flocks reared in the Zoo of Baghdad city [29]. The chemical composition values of both albumen and yolk of ostrich egg presented were also in range with values earlier presented by Superchi et al [30] as well as Szczerbińska et al [27]. Furthermore, the range of values of protein, lipids, ash, carbohydrates obtained in the present study for albumen and yolk contents in respect to chemical composition corroborated the works of Di Meo et al [31] and Caboni et al [32].

The means and standard errors of mineral compositions of albumen and yolk of ostrich eggs were presented in Table 2. The results revealed that yolk had higher values of $135.35,380.40,20.35,10.38,2.25,1.85$ and 2.50 in part per million for calcium, phosphorus, magnesium, iron, copper, zinc and manganese respectively than these parameters in albumen, while albumen contents were only higher in potassium (160.25 ppm) compare to yolk.

The study indicated that the values of $\mathrm{P}, \mathrm{Ca}, \mathrm{Mg}, \mathrm{K}, \mathrm{Fe}$, $\mathrm{Cu}, \mathrm{Zn}$ and $\mathrm{Mn}$ obtained were in line with the range of values obtained by Ferial et al [33] for ostrich eggs in Egypt. Al-Obaidi et al [29] reported similar range of values for $\mathrm{P}, \mathrm{Ca}, \mathrm{Mg}, \mathrm{K}, \mathrm{Fe}, \mathrm{Cu}, \mathrm{Zn}$ and $\mathrm{Mn}$ in their study. Al-Obaidi et al [34] found slightly higher values for Ostrich eggs in respect to mineral composition than the result in the present study. The variations in the values of 
chemical composition of both albumen and yolk might due to the many factors such as genetic constitutions of the animal, geographical location, types of feeds given to the birds, management practices and environmental influenced .

Table 2: Means and Standard errors of mineral composition of albumen and yolk of ostrich eggs

\begin{tabular}{lll}
\hline Variable (ppm) & Albumen & Yolk \\
\hline Phosphorus (P) & $20.35 \pm 2.34$ & $135.35 \pm 3.78$ \\
Calcium $(\mathrm{Ca})$ & $28.00 \pm 2.45$ & $380.40 \pm 10.56$ \\
Magnesium $(\mathrm{Mg})$ & $10.00 \pm 0.02$ & $20.35 \pm 2.05$ \\
Potassium $(\mathrm{K})$ & $160.25 \pm 8.88$ & $120.28 \pm 3.35$ \\
Iron $(\mathrm{Fe})$ & $3.25 \pm 0.03$ & $10.38 \pm 1.43$ \\
Copper $(\mathrm{Cu})$ & $0.90 \pm 0.01$ & $2.25 \pm 0.03$ \\
Zinc $(\mathrm{Zn})$ & $0.95 \pm 0.02$ & $1.85 \pm 0.06$ \\
Manganese $(\mathrm{Mn})$ & $1.50 \pm 0.03$ & $2.50 \pm 0.01$ \\
\hline
\end{tabular}

\section{4.o Conclusion}

This study showed that the range of values documented for both yolk and albumen contents in terms of chemical and mineral compositions were within the nutritional ranges for those consuming it.

\section{References}

1.Zakeri A., and Kashefi P. Proventricular-ventricular impa ction in ostrich (Struthio camelus). World Journal of Zoology, 2011, 6(4), 424-426.

2.Amao SR, Ojedapo LO, Adedeji TA, and Olugbemiga KS (2019). Principal Component Analysis Approach in describing the quality traits of Ostrich (Struthio camelus) eggs under Southern Guinea Savanna Region of Nigeria. Asian Journal of Biological Sciences, 2019, (In Press)

3.Horbanczuk JO. Current situation in ostrich farming and industry with special references to Middle and Eastern Europe. In: International Conference on Commercial Ostrich-Breeding Development, 30-July, 3, 2005, Pp. 1-8.

4.Cooper RG, Madeiros C, Villegas R, Hegab, IM, Mohammad MA, Ibrahim NS, Mahrose Kh MA and Glatz PC. Some regional thoughts on ostrich farming in arid zones. In: Proceedings of the XIV World Ostrich Congress, Riga, Latvia, October 19-20, 2007, pp 23-30

5.El-Safty S. and Mahrose Kh M. Evaluation of some phenotypic, physiological and egg quality traits of African black neck ostrich under arid desert conditions of Libya. International Journal of Poultry Science, 2009, 8 (6): 553-558
6.Mahrose KHM. Influences of stocking density and male: female ratio on the performance of ostrich under desert conditions of Egypt; Poultry Conference of 6th International Egypt: Porto - Marina, Alexandria;. 26-29 March 2012, pp. 170-183.

7.Gouda N, El-Sayiad Gh, Mahrose KHM, Elsayed, MA and Elarousy M. (2014). Effects of exposing ostrich eggs to doses of gamma irradiation on some blood biochemical and hormonal levels of chicks. Zag. J. Agric. Res., 2014, 41: 23- 34

8.Deeming DC. Introduction. The Ostrich: Biology, Production and Health.In: Deeming D.C, editor. Oxon: CABI publishing, Wallingford; 1999, pp. 1-9.

9.Minka NS. Evaluation of the performance of farmed ostrich chicks to juvenile age in Northern Nigeria. Tropical Journal Animal Science, 2003, 6:69-73.

10.Derfler PS. Ratite and squab mandatory inspection. Attachment to FSIS Constituent Update, April 20, 2001, p.2. <http:// www.fsis.usda.gov/oa/update/o42001att3.htm>.

11.Bovera F, Marono S, Di Meo C, Iannaccone F, Attia YA and Nizza A. Comparison of caecal and faeces fermentation characteristics of ostrich by in vitro gas production technique. Acta Agr. Scand. Section A, 2011. 61:72-79.

12.Cornetto T, Angel R and Estevez I. Influence of stocking density and dietary energy on ostrich (Struthio camelus) performance. Int. J. Poult. Sci., 2003, 2:102-106.

13.Bain M. Eggshell strength: A mechanical ultra-structural evaluation. Ph D. Thesis. University of Glasgow, Scotland, UK.1990.

14.Mertens K, Bamelis F, Kemps B, Kamers B, Verhoelst E, De Ketelaere E, Bain M, Decuypere E. and De Baerdemaeker J. Monitoring of eggshell breakage and eggshell strength in different production chains of consumption eggs. Poultry Science, 2006, 85: 1670-1677.

15.Davis C and Reeves R. High value opportunities from the chicken egg. A report for the Rural Industries Research and Development Corporation. South Africa, 2002.

16.Stadelman WJ. The incredibly functional egg. Poultry Sci.,1999, 78: 807-811.

17.Kovacs-Nolan JKN, Philips M and Mine Y. Advanced in the value of eggs and egg components for human health. J. Agric. Food Chem., 2005, 53:8421-8431.

18.Okoli IC and Udedibie ABI. Effect of palm kernel oil treatment and method of storage on internal quality, viability and hatchability of fertile chicken eggs. Trop. Agric. (Trinidad), 2001, 78:137-140.

19. Al-Obaidi FA, Al-Shadeedi SMJ and Al-Dalawi RH. Quality, chemical and microbial characteristics of table eggs at retail stores in Baghdad. International Journal of Poultry Science, 2011,10 (5): 381-385

20. Amao SR. Egg production and growth performance of Naked neck and Rhode Island Red chicken crosses under southern 
guinea savanna condition of Nigeria. International Journal of Agriculture and Earth Science,2017, 3(2): 1-10.

21.Association of Official Analytical Chemists. Official Methods of Analysis. 20th ed., Washington, D.C., 2005.

22. Shibusawa Y, Lino S, Shindo H. and Ito Y. Separation of chicken egg white proteins by high-speed countercurrent chromatography. J. Lipid Chromatogr. Relat. Technol., 200124:2007-2016.

23. Franey RJ and Elias A. Serum cholesterol measurement based on ethanol extraction and ferric chloride-sulfuric acid. Clin. Chim. Acta., 1968, 21:255-263.

24. Omana DA and Wu J. A new method of separating ovomucin from egg white. J. Agric. Food Chem., 2009, 57:3596-3603.

25. Omana, DA, Wang J and Wu J. Co-extraction of egg white proteins using ion-exchange chromatography from ovomucinremoved egg white. J. Chromatogr. B. Analyt. Technal. Biomed. Life Sci., 2010, 878:1771-1776.

26. SAS Institute. SAS/STAT User's Guide for Personal Computer. Release 12.12 SAS Institute, INC., Cary, N.C., USA. 2009.

27. Szczerbińska D and Wiercińska M. Comparison of the morphological structure and chemical composition of eggs in ratites, Electronic Journal of Polish Agricultural Universities, (EJPAU), 2010, 13(4):17-22

28. Selvan ST, Gopi H, Natrajan CP and Babu M. Physical characteristics, chemical composition and fatty acid profile of Os- trich eggs. International Journal of Science, Environment and Technology, 2014, 3(6): 2242-2249

29. Al-Obaidi FA and Al-Shadeedi SMJ. Comparison study of egg morphology, component and chemical composition of ostrich, emu and native chickens. Journal of Genetic and Environmental Resources Conservation, 2015, 3(2):132-137.

30. Superchi P, Sussi C, Sabbioni A. and Beretti V. Italian ostrich (Struthio camelus) eggs: physical characteristics and chemical composition. Annali Della Facoltà Di Medicina Veterinaria, 2002, XXII: 155-162.

31.Di Meo C, Stanco G, Cutrignelli MI, Castaldo S and Nizza A. Physical and chemica1 quality of ostrich eggs during the laying season. British Poult. Sci., 2003, 44:386-390.

32.Caboni MF, Boselli E, Messia MC, Velazco A, Fratianni G, Panfici ME. Effect of processing and storage on the chemical quality markers of spraying dried whole eggs.Food Chemisrty, 2005, 92: 293-303

33.Ferial AAS and Azza AA. Chemical, microbiological and sensory evaluation of mayonnaise prepared from ostrich eggs. Grasas Y. Aceities, 2008, 5 (4): 352-360.

34. Al- Obaidi FA, Al-Shadeedi SM and Mousa AS. Egg morphology, quality and chemical characteristics of Ostrich (Struthio camelus camelus). Al-Anbar Journal of Veterinary Science, 2012, 5 (1): 162-167. 